Article

\title{
Determinants of Internationalization as Levers for Sustainability: A Study of the Portuguese Pharmaceutical Sector
}

\author{
Jorge Vieira *, Rui Frade, Raquel Ascenso, Filipa Martinho and Domingos Martinho
}

Citation: Vieira, J.; Frade, R.; Ascenso, R.; Martinho, F.;

Martinho, D. Determinants

of Internationalization as Levers for Sustainability: A Study of the Portuguese Pharmaceutical Sector. Sustainability 2021, 13, 9792.

https://doi.org/10.3390/su13179792

Academic Editors: Yoshiki

Shimomura and Shigeru Hosono

Received: 3 July 2021

Accepted: 27 August 2021

Published: 31 August 2021

Publisher's Note: MDPI stays neutral with regard to jurisdictional claims in published maps and institutional affiliations.

Copyright: $@ 2021$ by the authors. Licensee MDPI, Basel, Switzerland. This article is an open access article distributed under the terms and conditions of the Creative Commons Attribution (CC BY) license (http://creativecommons.org/licenses/by/4.0/).
ISLA Santarém, Largo Cândido Reis, 2000-241 Santarém, Portugal; rui.frade@islasantarem.pt (R.F.); raquel.ascenso@islasantarem.pt (R.A.); filipa.martinho@islasantarem.pt (F.M.); domingos.martinho@islasantarem.pt (D.M.)

* Correspondence: vieira.jm@gmail.com

\begin{abstract}
The pharmaceutical industry is facing the pressure of a global economy, loss of value in local markets and the highly intense innovation that characterizes this sector. This has a heavy impact, particularly in smaller economies. With this investigation, we intend to identify the determinants of internationalization as levers for sustainability in the pharmaceutical export sector of a small economy. Data was collected from a sample representing $63 \%$ of the total universe, Portuguese pharmaceutical organizations with exporting activity. A contextualization of the sector and a bibliographic review were previously carried out, which laid the groundwork for the empirical framework. This study revealed a deeply internationalized sector conditioned by a few shortcomings, namely a certain lack of sustainable competitive advantages, relatively low investment in research and development (R\&D), insufficient innovation in internationalization strategies as well as scarce institutional support. Our findings may help pave the way for a more complete understanding of the dynamics of internationalization in highly competitive sectors.
\end{abstract}

Keywords: pharmaceutical industry; internationalization determinants; internationalization strategy; levers for sustainability

\section{Introduction}

"Big Pharma" dominates the global landscape. The major pharmaceutical firms are international players with considerable power in their home countries and substantial presence in much of the world's markets. Local companies need to survive in this environment [1,2]. This research consists of a study of local pharmaceutical companies to examine key variables, extracted from academic literature, that are associated with or contribute to the success of internationalization projects and, potentially, the organization's sustainability. Companies that, until recently, benefited from comfortable positions in local markets, can see those positions threatened by global competition [2]. This is the context in which we frame the Portuguese pharmaceutical industry (PPI), whose sustainability is currently considered at risk due to the sector's aggressive competitiveness for innovation and the demand for resources [1]. In this specific sector, sustainability strongly relies on international operations and, consequentially, internationalization emerges as a lever for economic and business sustainability.

In order to understand this phenomenon, we carried out a literature review to frame internationalization strategies within the scope of the pharmaceutical industry (PI). This review led us to isolate the research problem and to formulate the following research question: What are the determining factors for sustainability in the internationalization of the PPI? 
The exporting PPI faces the imperative of expanding to foreign markets as a source of self-sustainability. This study intends to be a small contribution to the body of knowledge of the internationalization processes, framed in an economy with few resources when compared to international players. At an operational level, we expect to identify strategic orientations and key factors for successful projects and better overall results from internationalization ventures.

\section{Background}

\subsection{Pharmaceutical Industry}

PI plays an undeniable role as a strategic sector to every country by contributing towards improving the population's quality of life [1,2]. This fact is expressed objectively by many indicators, from a higher life expectancy to the overall better quality of life of patients affected by numerous pathologies (oncology, AIDS, cardiovascular, the current pandemic situation, among others) or even by the impact that some drugs have on global economic indicators [1].

In the last twenty-five years, the majority of blockbuster medicines that supported the sustainability of Big Pharma, saw a drastic decrease in sales volume as a direct consequence of expiring patents. This was complemented by a burst in generic medicines sales across the global market, setting the stage for the development of companies with local or regional dimension that rapidly adapted their activities to the manufacture and commercialization of this type of products. However, less technologically complex activities (manufacturing of raw materials, intermediate products, and drugs with small or no differentiation) are associated with lower financial margins [3-5]. For this reason, the PI tends to develop new and innovative drugs, associated with much better margins, particularly during the period of exclusivity associated with innovation patents [5-7]. Nevertheless, the development of a new drug is a risky and resource-intensive endeavor. It frequently involves a strong financial investment, often over one billion euros [8], and long development times for a new medicine to be marketed. In the last twenty-five years, research and development $(R \& D)$ costs have tripled in Europe $[1,5]$.

Big Pharma tried to leverage the sustainability of these large investments by intensifying international efforts, with the goal of achieving swift returns on their investment, in a shorter period of time. Brand new medicines are usually associated with considerably higher sales prices, especially the most technologically sophisticated (for example, the new monoclonal antibodies for oncological pathologies) $[1,8]$. As such, despite the global increase in sales associated with generic medicines, characterized by having sales prices far below their brand equivalents, the international pharmaceutical market continues to grow remarkably (see Table 1).

Globally, the pharmaceutical market generates approximately 1060 billion euros. North America (United States and Canada) accounts for about 45\% of the market, Europe $23 \%$, China $10 \%$, Japan $7 \%$, and the remaining countries only $11 \%$. The Portuguese market is considered objectively small in the global context [9].

Table 1. World Pharmaceutical Market.

\begin{tabular}{ccccccc}
\hline & \multicolumn{2}{c}{2018} & \multicolumn{2}{c}{ 2019 } & \multicolumn{2}{c}{ 2020 } \\
\cline { 2 - 7 } & Sales & M.S. $\%$ & Sales & M.S.\% & Sales & M.S.\% \\
\hline North America & 433,262 & $44.7 \%$ & 457,197 & $44.4 \%$ & 478,676 & $45.3 \%$ \\
Europe & 215,882 & $22.3 \%$ & 229,876 & $22.3 \%$ & 240,379 & $22.7 \%$ \\
China & 105,859 & $10.9 \%$ & 115,607 & $11.2 \%$ & 103,408 & $9.8 \%$ \\
Japan & 72,429 & $7.5 \%$ & 73,973 & $7.2 \%$ & 72,732 & $6.9 \%$ \\
Latin America & 36,140 & $3.7 \%$ & 39,130 & $3.8 \%$ & 44,001 & $4.2 \%$ \\
Portugal & 3670 & $0.4 \%$ & 3860 & $0.4 \%$ & 3945 & $0.4 \%$ \\
Rest of World & 102,262 & $10.5 \%$ & 110,555 & $10.7 \%$ & 114,582 & $10.8 \%$ \\
\hline World & 969,504 & $100 \%$ & $1,030,199$ & $100 \%$ & $1,057,723$ & $100 \%$ \\
\hline
\end{tabular}

Sales: yearly annual turnover (million euros); M.S.\%: market share. Source [9]. 


\subsection{The Internationalization of Pharmaceutical Companies}

Internationalization has been the subject of intense investigation in the last decades, with the definition of several theories that explain this phenomenon from different perspectives. However, few are the papers specifically focused on studying PI's internationalization [7,10-23] (see Appendix A). When analyzing these studies we observed highly dispersed criteria, methodologies, and objectives. This limitation was also mentioned by other authors in previous research [7]. None of these studies investigate internationalization as a source of sustainability. The most frequently referred theoretical frameworks are the internationalization models based on resources [24], the incremental internationalization [25], and the eclectic paradigm [26]. These choices reflect researchers' concerns when evaluating the use of companies' internal resources and their ability to create the necessary conditions for international expansion while, simultaneously, identifying incremental internationalization trends, from sporadic exports to establishing manufacturing facilities abroad [27]. A set of attributes or determinants in the internationalization process were identified as well: international strategic orientation (ISO), entry mode selection (EM), competitive advantages (CA), internationalization barriers (IB), and the role of R\&D [7,8,11,12,14,15,19,22].

\subsection{The Portuguese Pharmaceutical Industry}

In a global context, the Portuguese pharmaceutical industry is relatively small, consisting mainly of small and medium-sized companies [28]. The domestic market is valued at approximately 3.95 billion euros, which represents only $0.4 \%$ of the global market [9]. Investment in innovation follows a slight upwards trend, virtually insignificant when compared to similar economies like Austria, Cyprus or Slovenia [1,29]. This paradigm reveals a situation of relative weakness, especially for companies for which the local market is the main source of income.

The history of the PPI's internationalization is relatively recent. In 2017, export figures were roughly one billion euros, about $2 \%$ of country's total exports [28,30]. Despite the recent surge in exports, the Portuguese pharmaceutical products' trade balance is strongly negative, -1489 million euros in 2017 [31], a fact that conditions the sustainability of the pharmaceutical sector.

PPI's export intensity (percentage of products sold abroad) has more than doubled since 2010. Similarly, the level of imports covered by exported goods or services in the pharmaceutical sector has increased twofold in recent years. This phenomenon was significantly more evident than in other industrial sectors. However, the penetration rate of imports in the domestic market (percentage of supply in the Portuguese market imported from abroad) is significantly larger than the national average and has increased in recent years, exposing the sector's strong dependence on foreign entities (see Table 2) [30]. These seemingly contradictory indicators are at the heart of this study's academic relevance and ambition.

Table 2. Export Economic Indicators for Portuguese Pharmaceutical Industry.

\begin{tabular}{ccccc}
\hline Mean Yearly Value\% & & 2008-2010 & 2011-2013 & 2014-2016 \\
\hline \multirow{2}{*}{ Export Intensity ${ }^{(1)}$} & PT & 14.0 & 17.9 & 19.5 \\
& PPI & 42.8 & 62.5 & 85.7 \\
\hline Coverage rate of imports by & PT & 70.9 & 87.8 & 90.3 \\
exports ${ }^{(2)}$ & PPI & 22.9 & 31.6 & 40.6 \\
\hline Import penetration rate on the & PT & 18.7 & 19.9 & 21.1 \\
domestic market (3) & PPI & 76.5 & 84.1 & 93.7 \\
\hline
\end{tabular}

(1) How much of the local production is exported. (2) What percentage of imports is offset by exports. ${ }^{(3)}$ How much of the local supply is imported. PT: Country's average; PPI: only Portuguese pharmaceutical industry. 


\section{Theoretical Framework}

The understanding of internationalization phenomena has undergone an enormous evolution since the 1960s, from the classic models based on economic power to models based on relations of multipolar cooperation. First theories were influenced by the postWorld War II environment and the strong internationalization movement of the American production industry [32]. These refer to the importance of acquiring resources for manufacturing goods or provide services to create profit. Company resources are the bedrock for developing sustainable competitive advantages [24,33-35]. In the later 1970s, new behavioral approaches emerged. The most cited in academic literature are the Uppsala incremental model [25] and the Eclectic paradigm [26]. Recently, new perspectives emerged, highlighting the significance of professional networking in internationalization decisions [36]. According to these new models, resource allocation is mediated through interactions between companies [37]. Despite the high volume of theories and experimental models, there is still no model that holistically explains internationalization and, above all, with practical applicability to support companies' strategic decision making [27,35].

\subsection{Determinants of Pharmaceutical Industry Internationalization}

The main goal of this study is not to identify the determining factors for internationalization performance. This has already been the subject of previous research, by other authors, which has greatly contributed to the body of knowledge in this field [38]. The characterization and relevance of such factors, however, are still somewhat limited, i.e., researchers find a lack of information when trying to identify the relevant determinants of internationalization in a specific economic sector. To overcome this limitation, our study follows a different path, studying the internationalization determinants previously identified in the literature that can be particularly relevant to the pharmaceutical sector. This enabled the identification of a set of variables, determinants of the sustainability in the pharma environment [7,11-23], further elaborated in the following points.

\subsubsection{Internationalization Strategic Orientation}

Managers' internationalization strategic orientation (ISO) is essential to understanding the need to expand operational activity to foreign markets, adequate allocation of resources, international strategy development, and, particularly, how opportunities in foreign markets are perceived and identified [39]. Reluctance in the adoption of internationalization strategies can be a consequence of insufficient determination by top managers [40] which, in turn, can be a limitation to the overall success of internationalization ventures. This means that one of the fundamental aspects in the definition of a company's foreign strategy is the attitude of the top managers since, too often, foreign expansion results in nothing more than the application of the local business plan to external markets [41,42].

Shoham [43] argued that the choice between different ISO's, by itself, would not impact international performance. He demonstrated that the subjective perception of internationalization factors did not suffer any variations from the different strategic orientations. However, the PPI is still heavily reliant on the domestic market and, as such, we propose the following hypotheses as a method for understanding the importance of the ISO in international performance:

Hypothesis 1a (H1a). Different ISOs have different levels of turnover.

Hypothesis $\mathbf{1 b}(\mathbf{H 1} \mathbf{b})$. Different ISOs have different levels of international business turnover. 


\subsubsection{Competitive Advantages}

A company's profitability is directly proportional to its ability to build and exploit advantages in the markets where it operates [24,44,45]. Competitive advantages (CA) arise fundamentally from the value that a company can create for customers, exceeding the cost associated with it. Sustained competitive advantages result from the creation of addedvalue strategies, as distinct and inimitable as possible, for competing companies $[3,24]$. The different sources of competitive advantages, costs (CCA), service (SCA), or product (PCA), reflect the company's ability to allocate its resources better than competing companies, in the creation of perceived value for its customers [46,47].

Kaleka and Morgan [48] studied the interactions between CA and performance in foreign markets, revealing the existence of positive correlations between CA and stronger international results. Ferreira and Simões [46] noted that the CCA have a positive impact on economic performance while the SCA and PCA only appear to positively affect the subjective parameters of internationalization performance. In this research we hypothesize the following:

Hypothesis 2a (H2a). Companies with more CA are associated with a larger turnover.

Hypothesis $\mathbf{2 b} \mathbf{b} \mathbf{H} \mathbf{2 b})$. Companies with more $C A$ are associated with larger international business turnover.

Hypothesis $\mathbf{2 c}(\mathbf{H} 2 \mathbf{c})$. Companies with more CA are associated with ISOs focused on foreign markets.

\subsubsection{Barriers in the Process of Internationalization}

The internationalization process can often become problematic, as companies are faced with obstacles while implementing planned strategies [49]. The complexity in registering new drugs, limited access to licenses or reimbursements from governmental entities and the existence of patents are good examples of barriers to the internationalization of pharmaceutical companies [7]. These barriers (IB) can have different effects: discourage internationalization by non-exporting companies, inhibit exporting attitudes, can induce disinvestment decisions or be the dissuading factor for an ex-exporting company to resume its internationalization projects [49]. Managers' international experience and professional networking can be important to minimize the perception of barriers to internationalization $[7,12,49,50]$. From a conceptual standpoint, we can divide these barriers into internal (IIB), inherent to the company, in regard to the strategic definition and allocation of resources, and external (EIB), related to the market environment and external context [49].

Anil et al. [51] evaluated the impact of IB's in internationalization performance. Contrary to what was expected, this research revealed a positive impact of EIB on international activities, a surprising result in the author's opinion. Safari and Saleh [52] found only one indirect negative result of IB in international results, through a mediating effect in the business strategy. Thus, we hypothesize that:

Hypothesis 3a (H3a). Companies with more IB are expected to have less international business turnover.

Hypothesis $3 \mathbf{b}(\mathbf{H} 3 \mathbf{b})$. Companies with more IB are expected to have less $C A$.

Hypothesis 3c (H3c). Companies with less IB are expected to have ISOs focused on foreign markets.

\subsubsection{Entry Mode Selection}


The choice of entry mode (EM) is one of the most important strategic decisions in an internationalization process [4]. It can have a direct impact on the project's performance since poor decisions can have lasting effects in the entire strategy and future options. EM can be grouped according to the need for required investment: no investment (WEM): exports, licensing contracts, franchising; or with investment (IEM): joint ventures, acquisitions, and establishment of subsidiaries [50]. The choice of EM is influenced, among other aspects, by the level of investment, risk exposure and the level of control that the company intends to have $[4,53]$.

It is not yet clear if EM is, in fact, a determinant in the process of a company's internationalization. In a recent review, Chan et al. [38] observed that this factor was given relatively low importance in academic research. It seems to serve more as a predictor of potential risks, operational control, and financial return, when conciliated with other determinants, namely IB $[4,7,53]$. Ulrich et al. [53] showed that IEM can have a positive impact in financial results as a consequence of higher investment levels and control over internationalization strategies and their implementation. While studying the internationalization process for pharmaceutical companies and the choice of EM, Wrona and Trąpczyński [7] noted that this decision results from weighting several aspects such as the market's potential or level of product differentiation to be marketed as well as managers' personal characteristics like international experience and risk perception. This led us to hypothesize:

Hypothesis 4 (H4). IEM corresponds to ISOs focused on foreign markets.

\subsubsection{The Role of R\&D}

Previous research established $R \& D$ activities in PI as a key determinant for sustainability in this particular sector $[1,5,6-8]$. While studying the Indian PI, Chitoor and Sougata [14] concluded about the importance of reinforcing investment and capacities in R\&D to improve companies' global competitiveness. They observed a strong correlation between companies with higher R\&D investment levels, higher financial results, and degree of internationalization. A strong bet in $R \& D$ is the reflection of a strategic predisposition for innovation and new product development. Rentala et al. [22] noticed an association between reduced R\&D levels and international performance. In a 2020 paper, Teramae et al. [54] framed the current PI's R\&D model around sustainability. After analyzing thirty internationalized PI companies, they found a surprising negative correlation between R\&D investment and revenue levels, despite the increase in total number of approved products. It is, therefore, crucial to understand if R\&D investment is associated with better financial returns for PPI. Thus, we expect that:

Hypothesis 5 (H5). Larger RED investment is associated with larger international business turnover.

\subsubsection{Internationalization Performance}

Internationalization performance has been the object of intense research in the last decades. Chen et al. [38], in a recent bibliographical review, highlighted over one hundred key factors with direct impact on it. This study aims to identify determinants specific to sustainability within the PPI scope, as previously stated. As such, we adopted a parsimonious perspective, selecting two economic indicators to evaluate internationalization performance: total revenue and internationalization intensity (revenue percentage directly attributed to international business) [22,48]. We formulate hypothesis $\mathrm{H}_{1 a}, \mathrm{H}_{1}, \mathrm{H}_{2}, \mathrm{H}_{2}, \mathrm{H}_{3}$, and $\mathrm{H}_{5}$, as previously presented, with the goal of identifying the determinants with relevant correlations with internationalization performance of the PPI.

\subsubsection{Research Framework}


The proposed framework can be seen in Figure 1. A set of variables was additionally included in our research, aiming to provide a better contextualization of the PPI sector, namely the years of international activity, the volume of countries where the company is present, the total number of employees, the percentage of employees allocated to international activity and the main international activity (see Appendix B).

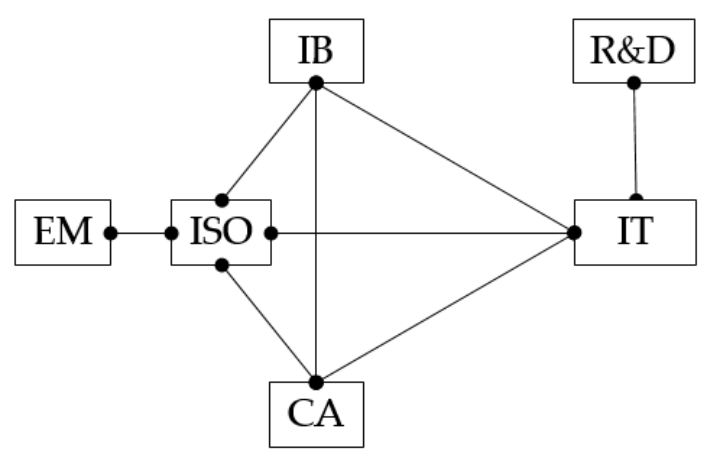

Figure 1. Research Framework. CA-Competitive Advantages. EM-Entry Mode. IBInternationalization Barriers. ISO-International Strategic Orientation. IT - International Turnover. R\&D-Research and Development.

\section{Methodology}

\subsection{Methodological Options}

This study is quantitative in its nature [55,56]. The research datum was collected through a structured questionnaire (see Appendix B and C). The main goal of this research is to study the sustainability determinants of the PPI, forced to compete in a global environment dominated by the so called "Big Pharma". For this reason, only the PPI manufacturers and exporters of pharmaceutical products (raw materials or drugs in their finished form) were selected. The selection was carried out by resorting to data from the Iberinform database [57]. We have selected all companies with the Portuguese activity classification (CAE) 21100 (basic pharmaceutical products manufacturer) and 21201 (medicine manufacturer). Data selection took place on the 18 September 2019. Eighty-two companies were selected according to these criterions. Sample validation was carried out using available information on each company's website and an additional contact via phone or email, when required, as to identify companies with current industrial and international activity. Sixty-six companies were excluded, thirty-four due to being subsidiaries and thirty-two because their current activity did not fall within the scope of our research. Thus, the final universe is comprised of sixteen companies that meet the eligibility criteria for this study: pharmaceutical company, producer, and exporter of pharmaceutical products, having Portugal as the center of international strategy's decisions.

Questionnaire datum was subjected to several tests, depending on the nature of the variables and the hypotheses being tested. We conducted a descriptive analysis on all variables; Spearman's' correlation tests were used to identify possible associations between ordinal variables; Mann-Whitney's non-parametric tests were performed to identify differences between nominal and ordinal variables. A reliability test was also applied to the questionnaire, using Cronbach's alpha calculation. In all tests, a significance level of $p=0.05$ or lower was used, when applicable [55,56,58]. All data analysis was carried out using $\mathrm{IBM}^{\odot}$ SPSS$^{\odot} 25$ and Microsoft $^{\odot}$ Excel 2016.

\subsection{Questionnaire and Scales}

In order to collect the required quantitative data, a questionnaire was developed using scales previously validated in the scientific literature $[43,48,59-62]$ as detailed in Appendix B. It underwent a reliability test to confirm its internal consistency, using the 
Cronbach's alpha calculation $[56,63,64]$. The complete questionnaire has a reasonable $\alpha=$ 0.691. This survey was conducted using the Google Forms platform [65].

\subsection{Sampling Process}

The target population is comprised of 16 companies. Due to the relatively small size of the universe in scope we opted for studying it in its entirety, as recommended [66,67]. Despite several attempts, we obtained a total of 10 responses, representing $63 \%$ of the universe, a significant value. We consider that this response rate was impacted by limitations derived from the pandemic situation in Portugal during the period when this study was being carried out. Since datum was not collected for the universe in full, we submitted our sample to an additional representativeness test [63]. We selected three variables and nine stratification items, based on data referenced in the literature on PI. High levels of representativeness were observed in all nine items, regardless of the stratification variable used. It is important to remember that the object of this investigation is a specific industrial sector of a country. All studies related to the internationalization of pharmaceutical companies are characterized by having relatively small samples (see Appendix A). According to Quivy and Campenhoudt [56] and the recommended prudence by Kruskal and Mosteller [67] regarding the use of the word "representativeness", considering that our sample is highly homogeneous, it is reasonable to conclude that it is representative of the studied sector. A pre-test was carried out, with two in-person questionnaires. This procedure confirmed that each question was correctly understood, allowing us to capture the desired perception of the original scales. Top managers from each company (members of the Board of Directors, General Managers, and International Senior Managers) were contacted between the 1 December 2019and the 31 March 2020, and invited to participate in this research.

\section{Findings}

\subsection{Descriptive Analysis}

Table 3 represents a summary of the descriptive analysis for all variables and dimensions.

Table 3. Descriptive Analysis.

\begin{tabular}{ccccc}
\hline Variable/Dimension & $\begin{array}{c}\text { No. } \\
\text { Items }\end{array}$ & Mean & Median & SD \\
\hline International Strategical Orientation (ISO) & 1 & 1.80 & 2.00 & 0.42 \\
Entry Mode (EM) & 1 & 1.20 & 1.00 & 0.42 \\
Competitive Advantages (CA) & 10 & 4.40 & 4.00 & 0.84 \\
Cost Competitive Advantages (CCA) & 2 & 4.20 & 4.00 & 0.92 \\
Service Competitive Advantages (SCA) & 5 & 4.50 & 4.50 & 0.85 \\
Product Competitive Advantages (PCA) & 3 & 3.90 & 4.00 & 0.74 \\
Internationalization Barriers (IB) & 12 & 4.40 & 4.50 & 0.97 \\
Internal Internationalization Barriers (IIB) & 6 & 4.10 & 4.00 & 1.10 \\
External Internationalization Barriers (EIB) & 6 & 4.80 & 5.00 & 0.79 \\
Years of International Activity & 1 & 5.00 & 4.50 & 1.25 \\
Countries with International Activity & 1 & 6.20 & 7.00 & 1.40 \\
Yearly Turnover & 1 & 5.00 & 5.00 & 2.00 \\
\% Turnover from international business & 1 & 4.60 & 4.50 & 1.90 \\
\% Turnover to R\&D & 1 & 4.20 & 4.00 & 2.39 \\
Total number of Employees & 1 & 6.20 & 7.00 & 1.03 \\
\% Employees to international business & 1 & 2.20 & 1.50 & 1.93 \\
Main International Activity & 1 & 1.80 & 2.00 & 0.42 \\
\hline
\end{tabular}

See Appendix B for item scale response sets. 
The descriptive analysis reveals that the PPI is comprised of companies significantly larger than the country's average business, in terms of global revenue and number of employees. The PPI shows relatively high international experience levels, both in activity duration and number of markets with reported activity. Nonetheless, the sector reveals a low degree of innovation within the remit of internationalization and reduced investments in R\&D, far below the sector's average at an international level [1,2]. The following points present some comments regarding researched variables.

\subsection{Hypotheses Confirmation}

\subsubsection{International Strategic Orientation}

Our findings suggest that the PPI defines its internationalization strategies focusing on target markets (mean $=1.8$; median $=2.0$ ). It was also confirmed that companies with ISO in foreign markets achieve higher financial results $(\mathrm{H} 1 \mathrm{a}, \mathrm{U}=0.500, p=0.042)$. The validation of H1a is in line with previous research [41,42]. H1b was not validated since no differences were evident regarding revenue generated from international activities (see Appendix D).

\subsubsection{Competitive Advantages}

It remains unclear whether CA provides a lever for internationalization (mean $=4.40$; median $=4.00$, at the center of the scale). When observed individually, each dimension appears to show greater emphasis on SCA (mean $=4.50$; median $=4.50)$, particularly when it comes to items related to customer satisfaction and technical/regulatory support provided to customers. However, there is no highlight in the PCA (mean =3.90; median = 4.00). Despite hypothesis H2a not being confirmed, from our investigation, it is visible that the perception of CA is generally associated with higher development levels, thus confirming hypothesis $\mathrm{H} 2 \mathrm{~b}$ and $\mathrm{H} 2 \mathrm{c}\left(r_{s}=0.693 ; p<0.05 ; \mathrm{U}=1.000 ; p=0.047\right.$ respectively), (see Appendix D). CA perception is positively associated with international revenue, as observed in the PCA. Internationalization strategies focused on external markets are associated with higher levels of CA, specifically PCA and CCA.

\subsubsection{Internationalization Barriers}

Our findings revealed a slight trend towards EIB (mean $=4.80$; median $=5.00$ vs. mean $=4.10$; median $=4.00$ on IIB) as the biggest obstacle to internationalization. Higher perceived levels of IB are negatively associated with companies with higher international revenue and CA levels. However, no evidence pointing to differences between IB perceptions in relation to ISO was found (see Appendix D, the validation of $\mathrm{H3a}, \mathrm{H} 3 \mathrm{~b}$ and the rejection of $\mathrm{H3c}$ ). Anil et al. [51] identified a surprising positive impact of EIB on internationalization performance (but not with IIB). Our results can be considered more consensual and in line with Barbosa et al.'s conclusions [19], when they observed that low institutional support had a negative influence on export performance. The most evident IB was the reduced support for internationalization ventures received from the Portuguese Government. Customs tariffs, regulatory requirements and cultural differences were also highlighted. These results enabled a better understanding of the barriers faced by PPI in their international projects.

\subsubsection{Entry Mode Selection}

In this research, we observed a clear preference for WEM selection, in $80 \%$ of the sample, with export activities being managed directly from Portugal or through contracts with local distributors (mean $=1.20$; median $=1.0$ ). None of the respondents chose foreign direct investment as the preferred EM. Other studies suggest IEM to be associated with higher levels of internationalization $[35,53]$ but not in our research since hypothesis $\mathrm{H} 4$, was not confirmed (see Appendix D). It seems EM is not a determinant of PPI's internationalization. 


\subsubsection{The Role of R\&D}

Our findings revealed strong positive correlations between the investment in R\&D and the most internationalized companies $\left(r_{s}=0.716 ; p<0.05\right)$ as well as with higher international turnover $\left(r_{s}=0.650 ; p<0.05\right)$, in line with previous research $[14,22]$. Reis and Forte [68] found that several characteristics of companies (ISO and size, for example) are important determinants of export intensity. Since this study did confirm hypothesis $\mathrm{H}_{5}$, (see Appendix D) our results partially confirm these conclusions, somehow contradicting research conclusion's by Teramae et al. [54].

\section{Discussion}

The Portuguese pharmaceutical export sector is composed of companies with a significant annual turnover, number of employees and international experience. The companies' dimension is significantly larger than the local sector's average. International experience is well consolidated, having exporting activity for over 15 years and being present in more than 50 countries. Their global results are considerably dependent on international business. In a recent study regarding the Portuguese industrial sector, Reis and Forte [68] established that the size of companies, measured by the number of employees, is a determinant of export intensity in industrial companies. In our study, a strong correlation between the number of employees and total turnover was also observed $\left(r_{s}=0.701 ; p=0.05\right)$. Exporting PPI seems to follow an internationalization model focused on developing the company's resources and CA which, in turn, have a positive impact on the degree of internationalization. These characteristics are similar to those found in Uppsala's internationalization model [25]. However, it is not possible to assume that the PPI's internationalization model follows an incremental pattern. We found that ISO is predominantly focused on foreign markets. We have also shown that these companies have significantly larger perception of $\mathrm{CA}$ and higher revenues, thus confirming what was stated in the literature review $[40,48]$. On the other hand, we observed that ISO focused on the Portuguese market acts as a barrier to international development, with a negative impact in internationalization intensity and outcomes.

Our study demonstrated that higher perceptions of CA correspond to lower perceptions of IB. It also revealed an interesting positive correlation between PCA development, larger international revenue, and $R \& D$ investment $\left(r_{s}=0.693 ; p=0.05\right.$ and $r_{s}=0.846 ; p=0.01$ respectively). However, CA was generally disregarded by the respondents, especially concerning attributes related to innovation and exclusivity, indicating a lack of competitiveness in this sector. Several authors $[6,7,14,48]$ found a strong association between CA related to innovation, $R \& D$, the development of innovative products and higher levels of internationalization and performance. Lower perception of PCA reveals a weakness as it represents a limitation to the sustainable development of internationalization. This is supported by the poor results in innovation indexes, given that only $20 \%$ of surveyed companies have innovative products as their main object of internationalization.

It was also possible to understand that companies significantly recognized the impact of IB, whether internal or external. Most notably, the limited support from Portuguese Institutions and the difficulties in obtaining reliable information from target markets. These findings suggest that Government institutions may play an important role as a lever for internationalization by providing institutional support to the sector.

Regarding EM selection, the PPI relies predominantly on EM's that do not require investment. None of the respondents chose foreign direct investment as the main EM, considered the highest degree of international development [50,53]. This may be related to the fact that this sector's international development is still at an early stage or, perhaps, the biggest limitation is the relative lack of resources and competitiveness on a global scale. 
Our study confirmed a strong positive correlation between R\&D investment and international revenue, in line with previous research [14,22], despite contradicting the unexpected findings from Teramae et al. [54], perhaps due to differences in the sample's characteristics and research design.

No associations were found between international experience and other studied variables. As such, we are led to conclude that, international experience does not have an impact on internationalization in PPI, in contrast to many citations found in the literature $[44,68]$. Buckley and Chapman [11] postulated that internationalization attitude can be conditioned by the mid-level managers' view, with direct implications for overall results. Perhaps, an analogous conclusion can be drawn from this study, regarding the exporting PPI. Another possible argument can be that exported products are characterized by their low innovation levels and, consequentially, shorter margins, but this would have to be confirmed in future research, as we do not have enough evidence to support this claim.

Figure 2 represents the relations between determinants confirmed throughout this study. The nature of this analysis and the tests that were performed do not permit the identification of eventual dependencies or mediator variables [58]. Still, it is possible to understand existing interdependencies between these factors and how they relate to the internationalization process and sustainability within the PPI. CA is associated with ISO and lower perception of IB. These determinants, as well as R\&D, are associated with higher internationalization turnovers. On the other hand, EM does not appear to be a determinant, hence why it was excluded from the final model.

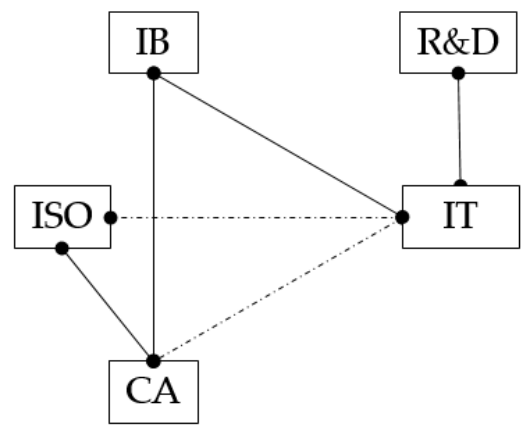

Figure 2. The working model. Solid Lines-confirmed paths. Dashed lines-partially confirmed paths. CA-Competitive Advantages. IB-Internationalization Barriers. ISO-International Strategic Orientation. IT - International Turnover. R\&D-Research and Development.

\section{Conclusions, Limitations and Future Directions}

The Portuguese exporting pharmaceutical sector accounts for about $2 \%$ of total Portuguese exports [28] and is considerably more export intensive than the country's overall industrial sector [30] with volumes potentially doubling in the next three to five years [69]. This sector assumes an evident strategic relevance in the Portuguese economic context. The increase in international activity also stems from the loss of profitability in the domestic market, which is still the main source of income for most companies in this sector. Exporting PPI companies have a reasonable international experience and tend to build their strategies with focus on foreign markets. However, per se, this is not enough to guarantee better results since international experience seems to have a limited impact on global outcomes. One possible explanation is, perhaps, the fact that $80 \%$ of sampled companies export commodity products, with no innovative or differentiating characteristics. This fact may be connected to previous opportunities in the local market. However, this does not seem to grant the necessary edge for competing locally or in a globalized market. It is clear that this is not the way for achieving sustainable development, internally or abroad. These conclusions suggest that the focus should be placed on investing in innovative and differentiating activities, enabling the creation of more sustainable, long-term internationalization strategies. It is also very clear the existing 
gap in institutional support to internationalization. Institutions that oversee this sector should increase their knowledge regarding the barriers that affect these companies and focus their cooperation and assistance efforts on the international expansion of PPI.

This research's small sample conditioned the selection of some statistical tests, limiting our options to those presented throughout this work [58]. As a suggestion, future studies may focus on the development of a conceptual internationalization model, specific to the pharmaceutical sector, grounded on the theoretical foundations previously presented.

Author Contributions: Conceptualization, J.V. and R.F.; methodology, J.V. and R.F.; software, J.V., R.F. and R.A.; validation, J.V., R.F. and R.A.; formal analysis, J.V.; investigation, J.V. and R.F.; resources, F.M. and D.M.; data curation, J.V. and R.F.; writing-original draft preparation, J.V., R.F., R.A., F.M. and D.M.; writing - review and editing, J.V.; supervision, D.M. All authors have read and agreed to the published version of the manuscript.

Funding: This research received no external funding.

Acknowledgments: The authors wish to thank the Editors and the referees for their constructive guidance.

Conflicts of Interest: The authors declare no conflict of interest.

\section{Appendix A}

Table A1. Studies on the Internationalization of Pharmaceutical Companies.

\begin{tabular}{|c|c|c|c|c|c|}
\hline Reference & Study Type & Object of Study & $\begin{array}{c}\text { Internationalization } \\
\text { Theory } \\
\end{array}$ & $\begin{array}{c}\text { Sample } \\
\text { (Companies) }\end{array}$ & $\begin{array}{c}\text { Internationalization } \\
\text { Determinants }\end{array}$ \\
\hline $\begin{array}{c}\text { Fina and Rugman } \\
\text { (1996) [12] }\end{array}$ & Empirical & $\begin{array}{c}\text { Internationalization } \\
\text { Strategies }\end{array}$ & Uppsala & 1 & EM, IB \\
\hline $\begin{array}{c}\text { Buckley and } \\
\text { Chapman } \\
(1997)[11]\end{array}$ & Empirical & $\begin{array}{c}\text { Internationalization } \\
\text { Strategies }\end{array}$ & Uppsala & 10 & ISO \\
\hline Javalgi and & & & & & \\
\hline $\begin{array}{l}\text { Wright } \\
(2003)[13]\end{array}$ & Conceptual & Entry Mode & & & EM, IB, ISO \\
\hline $\begin{array}{c}\text { Chittoor and } \\
\text { Sougata } \\
(2007)[14] \\
\end{array}$ & Empirical & $\begin{array}{c}\text { Internationalization } \\
\text { Strategies }\end{array}$ & Cluster Analysis & 40 & CA \\
\hline $\begin{array}{c}\text { Kuntluru et al. } \\
\text { (2012) [15] }\end{array}$ & Empirical & $\begin{array}{c}\text { Internationalization } \\
\text { Strategies }\end{array}$ & Life Cicle & 103 & EM \\
\hline $\begin{array}{c}\text { Wrona and } \\
\text { Trapczynski } \\
(2012)[7]\end{array}$ & Empirical & $\begin{array}{c}\text { Internationalization } \\
\text { Strategies }\end{array}$ & OLI & 5 & CA, EM, IB \\
\hline $\begin{array}{l}\text { Chitour } \\
(2013)[16]\end{array}$ & Conceptual & Entry Mode & & & EM, IB \\
\hline $\begin{array}{l}\text { Mowla et al. } \\
(2014)[17]\end{array}$ & Empirical & $\begin{array}{c}\text { Internationalization } \\
\text { Strategies }\end{array}$ & OLI & 1 & EM \\
\hline $\begin{array}{l}\text { Campins } \\
(2015)[18]\end{array}$ & Empirical & $\begin{array}{c}\text { Internationalization } \\
\text { Strategies }\end{array}$ & $\begin{array}{c}\text { Uppsala } \\
\text { Resources and } \\
\text { Capacities }\end{array}$ & 2 & EM \\
\hline $\begin{array}{c}\text { Barbosa et al. } \\
(2016)[19]\end{array}$ & Empirical & $\begin{array}{c}\text { Internationalization } \\
\text { Strategies }\end{array}$ & $\begin{array}{c}\text { Resources and } \\
\text { Capacities }\end{array}$ & 163 & IB \\
\hline $\begin{array}{l}\text { Diaz et al. } \\
(2017)[20]\end{array}$ & Empirical & $\begin{array}{c}\text { Internationalization } \\
\text { Strategies }\end{array}$ & & 1 & CA \\
\hline $\begin{array}{c}\text { Pereira and } \\
\text { Gomes } \\
(2017)[21]\end{array}$ & Empirical & $\begin{array}{c}\text { Internationalization } \\
\text { Strategies }\end{array}$ & $\begin{array}{c}\text { OLI } \\
\text { Uppsala }\end{array}$ & 4 & EM \\
\hline
\end{tabular}




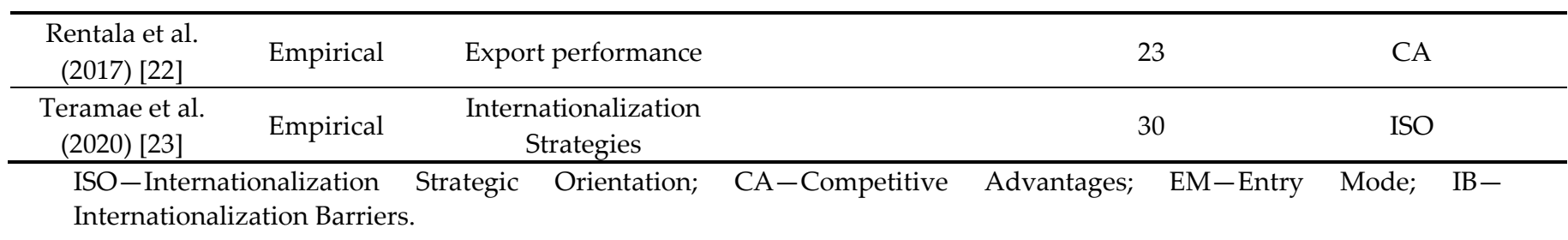

\section{Appendix B}

Table A2. Variables, Dimensions and Scale Type.

\begin{tabular}{|c|c|c|c|c|}
\hline Variable & Dimension & Items & Comments & Scale \\
\hline $\begin{array}{l}\text { Internationalization } \\
\text { Strategic Orientation } \\
\quad \text { (ISO) }[43,59]\end{array}$ & & 1 & $\begin{array}{c}\text { Do managers have an effective "international } \\
\text { mindset" or do they replicate the "local strategy" } \\
\text { on foreign markets. } \\
\text { 1: Focus on local market; } 2 \text { : Focus on foreign } \\
\text { markets. * }\end{array}$ & $\begin{array}{l}\text { Nominal, two } \\
\text { point }\end{array}$ \\
\hline Entry Mode (EM) [61] & & 1 & $\begin{array}{l}\text { Strategies for penetrating foreign markets. } \\
\text { 1: no direct financial investment (export and } \\
\text { licensing); 2: direct financial investment (Joint } \\
\text { ventures, direct investment) * }\end{array}$ & $\begin{array}{l}\text { Nominal, two } \\
\text { point }\end{array}$ \\
\hline $\begin{array}{l}\text { Competitive Advantages } \\
\text { (CA) [48] }\end{array}$ & $\begin{array}{c}\text { Cost }(\mathrm{CCA}) \\
\text { Service (SCA) } \\
\text { Product (PCA) }\end{array}$ & $\begin{array}{l}2 \\
5 \\
3\end{array}$ & $\begin{array}{l}\text { Capture the different competitive advantages and } \\
\text { their relevance for international activity. } \\
\text { 1: Fully disagree;...; 4: Neither disagree or agree;...; } \\
\text { 7: Fully Agree * }\end{array}$ & $\begin{array}{l}\text { Ordinal, seven- } \\
\text { point Likert }\end{array}$ \\
\hline $\begin{array}{l}\text { Internationalization } \\
\text { Barriers (IB) [51] }\end{array}$ & Internal (IIB) & 6 & $\begin{array}{l}\text { Captures the main barriers for internationalization } \\
\text { and whether these are internal or external to the } \\
\text { company. } \\
\begin{array}{r}\text { 1: Fully disagree;...; } 4 \text { : Neither disagree or agree;...; } \\
\text { 7: Fully Agree * }\end{array}\end{array}$ & $\begin{array}{l}\text { Ordinal, seven- } \\
\text { point Likert }\end{array}$ \\
\hline $\begin{array}{c}\text { Years of International } \\
\text { Activity }[46,48]\end{array}$ & & 1 & $\begin{array}{l}1:<5 \text { years; } 2: 5-10 \text { years; } 3: 11-15 \text { years; } 4: 16-20 \\
\text { years; } 5: 21-25 \text { years; } 6: 26-30 \text { years; } 7:>30 \text { years }\end{array}$ & $\begin{array}{l}\text { Ordinal, seven } \\
\text { point }\end{array}$ \\
\hline $\begin{array}{l}\text { Countries with Intern. } \\
\text { Activity }[46,48]\end{array}$ & & 1 & $\begin{array}{l}\text { 1: No int. activity; } 2:<10 \text { countries; } 3: 10-20 \\
\text { countries; } 4: 21-30 \text { countries; } 5: 31-40 \text { countries; } 6 \text { : } \\
\text { 41-50 countries; } 7:>50 \text { countries }\end{array}$ & $\begin{array}{l}\text { Ordinal, seven } \\
\text { point }\end{array}$ \\
\hline Yearly Turnover [61] & & 1 & $\begin{array}{c}\text { 1: <25 M€; 2: 26-50 M€; 3: 51-75 M€; 4: 76-100 M€; } \\
\text { 5: 101-150 M€; 6: 151-200 M€; 7: >200 M€ }\end{array}$ & $\begin{array}{l}\text { Ordinal, seven } \\
\text { point }\end{array}$ \\
\hline $\begin{array}{l}\text { \% International business } \\
\text { turnover }[46,48] \\
\end{array}$ & & 1 & $\begin{array}{c}1:<15 \% ; 2: 15-30 \% ; 3: 31-45 \% ; 4: 46-60 \% ; 5: 61- \\
75 \% ; 6: 76-90 \% ; 7:>90 \%\end{array}$ & $\begin{array}{l}\text { Ordinal, seven } \\
\text { point }\end{array}$ \\
\hline $\begin{array}{l}\text { Total number of } \\
\text { Employees [61] }\end{array}$ & & 1 & $\begin{array}{c}1:<50 ; 2: 51-100 ; 3: 101-200 ; 4: 201-300 ; 5: 301-400 \\
6: 401-500 ; 7:>500\end{array}$ & $\begin{array}{l}\text { Ordinal, seven } \\
\text { point }\end{array}$ \\
\hline $\begin{array}{c}\text { \% International business } \\
\text { employees }[46,48]\end{array}$ & & 1 & $\begin{array}{c}1:<15 \% ; 2: 15-30 \% ; 3: 31-45 \% ; 4: 46-60 \% ; 5: 61- \\
75 \% ; 6: 76-90 \% ; 7:>90 \%\end{array}$ & $\begin{array}{l}\text { Ordinal, seven } \\
\text { point }\end{array}$ \\
\hline R\&D Investment $[14]$ & & 1 & $\begin{array}{l}\text { \% Total turnover attributed to R\&D investment. } \\
\begin{array}{c}\text { 1: }<6 \% ; 2: 6-8 \% ; 3: 9-11 \% ; 4: 12-14 \% ; 5: 15-17 \% ; 6: \\
18-20 \% ; 7:>20 \%\end{array}\end{array}$ & $\begin{array}{l}\text { Ordinal, seven } \\
\text { point }\end{array}$ \\
\hline $\begin{array}{c}\text { Main International } \\
\text { Activity }\end{array}$ & & 1 & 1: innovative products; 2 : commodities/others & $\begin{array}{l}\text { Nominal, two } \\
\text { point }\end{array}$ \\
\hline
\end{tabular}




\section{Appendix C. Variable's Questionnaire}

ISO Question: Which countries influence the most and/or condition the definition of your company's internationalization strategy? 1-The Portuguese market, our main market; $2-$ The market where we intend to operate.

EM Question: Entry mode most frequently used when exploring new markets. 1: no direct financial investment (export and licensing); 2: direct financial investment (joint ventures, direct investment).

CA Questions: (1-3: CCA dimensions; 4-7: SCA dimensions; 8-10: PCA dimensions). Regarding the portfolio of products sold internationally, indicate the degree to which you agree or disagree with each of the following sentences: 1-Our manufacturing costs are very competitive, generally lower than our competitors. 2 -The sales prices we offer our international customers are very competitive, generally lower than those offered by our competitors. 3-Our delivery times to customers, from ordering to actual shipment of the product, are generally lower and better than those practiced by our competitors. $4-$ The technical and regulatory support we provide to international customers is generally superior to that of our competitors. 5-In destination markets, users (patients/consumers) highly value our products. 6-Customer accessibility to our products / portfolio is superior to that of our competitors. 7-Our customers are very satisfied with the overall quality of the service we provide. 8 -The scale of our product offering in international markets is generally superior to that of our competitors. 9-The quality of our products is very high, on average higher than that offered by our competitors. 10-The portfolio of products sold in international market is predominantly innovative and exclusive, which is a great advantage over our competitors.

IB Questions: (1-6: IIB dimension; 7-12: EIB dimension). Do you consider that the following situations condition or constitute barriers to international activity? $1-\mathrm{We}$ struggle to receive/obtain reliable information from international markets. $2-$ We have problems with after-sales support and sales follow - up in international markets. 3-My company still has a reduced internationalization culture. 4 -International business has a very high level of risk. 5-My company has difficulty managing logistics in the destination markets. 6-There are many communication problems with branches. 7Cultural differences in foreign markets are difficult to manage and overcome. $8-\mathrm{We}$ struggle to understand/manage the institutional environment (legal, fiscal) in foreign markets. 9-The Portuguese State offers limited support for internationalization initiatives. 10-Managing regulatory requirements in target markets is difficult. 11-The existence of product/manufacturing patents in force in the target markets prevents us from marketing our products. 12-Customs tariffs imposed by some countries take away our competitiveness. 


\section{Appendix D}

Table A3. Hypotheses Validation.

\begin{tabular}{|c|c|c|c|}
\hline Hypothesis & Test & Result & $\begin{array}{l}\text { Hypothesis } \\
\text { Validation }\end{array}$ \\
\hline H1a. Different ISOs have different levels of turnover & Mann-Whitney & $\begin{array}{l}\mathrm{U}=0.500 \\
p=0.042\end{array}$ & Yes \\
\hline $\begin{array}{l}\text { H1b. Different ISOs have different levels of international business' } \\
\text { turnover }\end{array}$ & Mann-Whitney & $\begin{array}{l}\mathrm{U}=1.500 \\
p=0.086\end{array}$ & No \\
\hline H2a. Companies with more CA are associated with a bigger turnover & Spearman's Correlation & $\begin{aligned} r s & =0.313 \\
p & >0.05\end{aligned}$ & No \\
\hline $\begin{array}{l}\text { H2b. Companies with more CA are associated with bigger } \\
\text { international business' turnover }\end{array}$ & Spearman's Correlation & $\begin{array}{c}r s=0.693 \\
p<0.05\end{array}$ & Yes \\
\hline $\begin{array}{l}\text { H2c. Companies with more CA are associated with an ISO focused on } \\
\text { foreign markets }\end{array}$ & Mann-Whitney & $\begin{array}{l}\mathrm{U}=1.000 \\
p=0.047\end{array}$ & Yes \\
\hline $\begin{array}{l}\text { H3a. Companies with more IB are expected to have less international } \\
\text { business' turnover }\end{array}$ & Spearman's Correlation & $\begin{array}{c}r s=-0.717 \\
p<0.05\end{array}$ & Yes \\
\hline H3b. Companies with more IB are expected to have less $C A$ & Spearman's Correlation & $\begin{array}{c}r s=-0.785 \\
p<0.01\end{array}$ & Yes \\
\hline $\begin{array}{l}\text { H3c. Companies with less IB are expected to have ISO's focused on } \\
\text { foreign markets }\end{array}$ & Mann-Whitney & $\begin{array}{l}\mathrm{U}=4.000 \\
p=0.273\end{array}$ & No \\
\hline H4. IEM corresponds to ISO's focused on foreign markets & Mann-Whitney & $\begin{array}{l}\mathrm{U}=6.000 \\
p=0.453\end{array}$ & No \\
\hline $\begin{array}{l}\text { H5. Large RED investment is associated with bigger international } \\
\text { business' turnover }\end{array}$ & Spearman's Correlation & $\begin{aligned} r s & =0.650 \\
p & <0.05\end{aligned}$ & Yes \\
\hline
\end{tabular}

\section{References}

1. EFPIA. The Pharmaceutical Industry in Figures. The European Federation of Pharmaceutical Industries and Associations. Available online: www.efpia.eu (accessed on 20 May 2021).

2. APIFARMA. The Pharmaceutical Industry in Portugal, Knowing How to Invest, Knowing How to Innovate, 75 Years Old; Apifarma: Lisbon, Portugal, 2014.

3. Barney, J.; Wright, M.; Ketchen, D. The resource-based view of the firm: Ten years after 1991. J. Manag. $2001,27,625-641$.

4. Hollensen, S. Global Marketing: A Decision-Oriented Approach, 5th ed.; Pearson Education: Harlow, UK, 2011.

5. Karampli, E.; Souliotis, K.; Polyzos, N.; Kyriopoulos, J.; Chatzaki, E. Pharmaceutical innovation: Impact on expenditure and outcomes and subsequent challenges for pharmaceutical policy, with a special reference to Greece. Hippokratia 2014, 18, 100106.

6. Bartlett, C.; Ghoshal, S. Going global: Lessons from late movers. Harv. Bus. Rev. 2000, 78, 132-145.

7. Wrona, T.; Trąpczyński, P. Re-explaining international entry modes: Interaction and moderating effects on entry modes of pharmaceutical companies into transition economies. Eur. Manag. J. 2012, 30, 295-315.

8. DiMasi, J.; Grabowski, H.; Hansen, R. Innovation in the pharmaceutical industry: New estimates of R\&D costs. J. Health Econ. 2016, 47, 20-33.

9. International Screening Year 2020. IQVIA. Available online: https://www.iqvia.com/ (accessed on 20 May 2021).

10. Penrose, E. The Theory of the Growth of the Firm; Blackwell: Oxford, UK, 1959.

11. Buckley, P.; Chapman, M. A longitudinal study of the internationalization process in a small sample of pharmaceutical and scientific instrument companies. J. Mark. Manag. 1997, 13, 43-55.

12. Fina, E.; Rugman, A. A test of internalization theory and internationalization theory: The Upjohn company. Manag. Int. Rev. 1996, 36, 199-213.

13. Javalgi, R.; Wright, R. An international market entry model for pharmaceutical companies: A conceptual framework for strategic decisions. Int. J. Med. Mark. 2003, 3, 274-286.

14. Chittoor, R.; Sougata, R. Internationalization paths of Indian pharmaceutical firms: A strategic group analysis. J. Int. Man. 2007, 13, 338-355.

15. Kuntluru, S.; Muppani, V.; Khan, A. Foreign direct investment and export performance of pharmaceutical firms in India: An empirical approach. Int. J. Econ. Fin. 2012, 4, 216-226.

16. Chitour, H. Big pharma in China: The driving forces behind their success: A qualitative analysis. Chin. Stud. 2013, 2, 169-177. 
17. Mowla, M.; Hoque, N.; Mamun, A.; Uddin, M. Entry mode selection, location choice and the sequence of internationalization: A case study on Ranbaxy laboratories Ltd. Asian Soc. Sc. 2014, 10, 145-154.

18. Campins, M. Modalities for the internationalization of Argentine pharmaceutical companies from a historical perspective: The Cases of Bagó and Sidus. Apuntes 2015, 42, 95-136.

19. Barbosa, D.; Ayala, A.; Sandoval, A. The Colombian pharmaceutical industry: Factors affecting export. Eur. J. Manag. Bus. Econ. 2016, 25, 39-46.

20. Díaz, H.; Lenis, J.; Rizo, A. Internationalization process in the pharmaceutical sector: The case of the Colombian company Tecnoquímicas. Est. Ger. 2017, 33, 421-437.

21. Pereira, A.; Gomes, J. A study of the internationalization strategies of the Brazilian pharmaceutical industries. Account. Org. Mag. 2017, 11, 68-79.

22. Rentala, S.; Anand, B.; Shaban, M. Determinants of export performance: An empirical analysis of the Indian pharmaceutical and automobile industries. In International Business Strategy; Palgrave Macmillan, London, UK, 2017; pp. 241-257.

23. Teramae, F.; Makino, T.; Lim, Y.; Sengoku, S.; Kodama, K. International Strategy for Sustainable Growth in Multinational Pharmaceutical Companies. Sustainability 2020, 12, 867.

24. Barney, J. Firm resources and sustained competitive advantage. J. Manag. 1991, 17, 99-120.

25. Johanson, J.; Vahlne, J.E. The internationalization process of the firm: A model of knowledge development and increasing foreign markets commitments. J. Int. Bus. 1977, 8, 23-32.

26. Dunning, J. The eclectic (OLI) paradigm of international production: Past, present and future. Int. J. Econ. Bus. 2001, 8, 173-190.

27. Ribau, C.; Moreira, A.; Raposo, M. Internationalization of the firm theories: A schematic synthesis. Int. J. Bus. Glob. 2015, 15, 528-554.

28. AICEP. Flash Pharmaceutical Industry. Available online: www.portugalglobal.pt/ (accessed on 20 December 2020).

29. APIFARMA, Portuguese Pharmaceutical Data. Available online: https://www.apifarma.pt (accessed on 20 August 2019).

30. INE. Portuguese Statistic Indicators. Available online: www.ine.pt (accessed on 20 August 2019).

31. Pordata. Portuguese Economic Indicators. Available online: www.pordata.pt (accessed on 10 September 2019).

32. Kor, Y.; Mahoney, J.; Siemsen, E.; Tan, D. Penrose's the theory of the growth of the firm: An exemplar of engaged scholarship. Prod. Oper. Manag. 2016, 25, 1727-1744.

33. Morgan, N.; Kaleka, A.; Katsikeas, C. Antecedents of export venture performance: A theoretical model and empirical assessment. J. Mark. 2004, 68, 90-108.

34. Williamson, O. Markets and Hierarchies: Analysis and Antitrust Implications. A study in the Economics of Internal Organization; The Free Press: New York, NY, USA, 1975.

35. Andersen, P.; Ahmad, S.; Chan, W. Revisiting the theories of internationalization and foreign market entry mode: A critical review. Int. J. Bus. Comm. 2014, 4, 37-86.

36. Johanson, J.; Mattsson, L. Internationalization in industrial systems: A network approach. In Strategies in Global Competition; Hood, N., Vahlne, J.E., Eds.; Croom Helm: New York, NY, USA, 1988.

37. Cunningham, M.; Culligan, K. Competitiveness through networks of relationships in information technology product markets. In Proceedings of the 4th IMP International Conference, Manchester, UK, 7-9 September 1988; pp. 156-180.

38. Chen, J.; Sousa, C.; Xinming, H. The determinants of export performance: A review of the literature 2006-2014. Int. Mar. Rev. 2016, 33, 626-670.

39. Cavusgil, S.; Bilkey, W.; Tesar, G. A note on the export behavior of firms: Exporter profiles. J. Int. Bus. Stu. 1979, 10, 91-104.

40. Cavusgil, S.; Nevin, J. Internal determinants of export marketing behavior: An empirical investigation. J. Mark. Res. 1981, 18, 114-119.

41. Wind, Y.; Douglas, S.; Perlmutter, H. Guidelines for developing international marketing strategies. J. Mark. 1973, $37,14-23$.

42. Perlmutter, H. The tortuous evolution of the multinational corporation. Prac. Man. 1969, 17, $13-18$.

43. Shoham, A. The EPRG Framework: Does it Affect Managerial Perceptions of Export Success? In Global Perspectives in Marketing for the 21st Century. Developments in Marketing Science, Proceedings of the Academy of Marketing Science, Qawra, Malta, 23 June 1999; Springer: Cham, Germany, 2015.

44. Johansson, J. Global Marketing: Foreign Entry, Local Marketing and Global Management, 5th ed.; McGraw Hill: New York, NY, USA, 2008.

45. Porter, M. Competitive Advantage: Creating and Sustaining Superior Performance; Free Press: New York, NY, USA, 1985.

46. Ferreira, M.; Simões, L. The interrelationships between resources, capabilities, export competitive advantages and export performance. Int. J. Exp. Mark. 2016, 1, 142-165.

47. Freire, A. Strategy, Success in Portugal; Verbo: Lisbon, Portugal, 2003.

48. Kaleka, A.; Morgan, N. Which competitive advantage? Competitive advantage: Market performance relationships in international markets. J. Int. Mar. 2017, 25, 25-49.

49. Kahiya, E. Five decades of research on export barriers: Review and future directions. Int. Bus. Rev. 2018, 27, 1172-1188.

50. Root, F. Entry Strategies for International Markets; Lexington Books: New York, NY, USA, 1994.

51. Anil, N.; Shoham, A.; Pfajfar, G. How export barriers, motives, and advantages impact export performance in developing countries. Int. J. Exp. Mark. 2016, 1, 117-141.

52. Safari, A.; Saleh, A. Key determinants of SMEs' export performance: A resource-based view and contingency theory approach using potential mediators. J. Bus. Ind. Mar. 2020, 35, 635-654. 
53. Ulrich, A.; Boyd, B.; Hollensen, S. Financial Performance of Entry Mode Decisions: Effects of Control in an Internationalization Context. Int. J. Bus. Man. 2012, 24, 12-28.

54. Teramae, F.; Makino, T.; Lim, Y.; Sengoku, S.; Kodama, K. Impact of Research and Development Strategy on Sustainable Growth in Multinational Pharmaceutical Companies. Sustainability 2020, 12, 5358.

55. Bryman, A.; Cramer, D. Data Analysis in Social Sciences: Introduction to Techniques Using SPSS for Windows, 3rd ed.; Celta Editores: Oeiras, Portugal, 2003.

56. Quivy, R.; Campenhoudt, L. Research Manual in Social Sciences, 4th ed.; Gradiva: Lisbon, Portugal, 2005.

57. Iberinform. Available online: www.iberinform.pt (accessed on 20 November 2019).

58. Morgan, C. Use of proper statistic technics for research studies with small samples. Am. J. Physiol. Lung Cell Mol. Physiol. 2017, 313, 873-877.

59. Shoham, A.; Rose, G.; Albaum, G. Export motives, psychological distance and the EPRG framework. J. Glob. Mark. 1995, 8, 937.

60. Daszkiewicz, N.; Wach, K. Motives for going international and entry modes of family Firms in Poland. J. Int. Man. 2014, 6, 518.

61. Oliveira, J.; Yazdani, N.; Cadogan, J.; Hodgkinson, I.; Tsougkou, E.; Jean, R.; Story, V.; Boso, N. The empirical link between export entry mode diversity and export performance: A contingency-and institutional-based examination. J. Bus. Res. 2018, 88, 505-512.

62. Zou, S.; Fang, E.; Zhao, S. The effect of export marketing capabilities on export performance: An investigation of Chinese exporters. J. Int. Mark. 2003, 11, 32-55.

63. Field, A. Discovering Statistics using SPSS; Artmed: Porto Alegre, Brasil, 2009.

64. Pestana, M.; Gageiro, J. Data Analysis for Social Sciences: The Complementarity of SPSS; Syllable: Lisbon, Portugal, 2005.

65. Google Forms. Available online: www.forms.google.com (accessed on 30 March 2020).

66. Krejcie, M.; Morgan, D. Determining sample size for research activities. Edu. Psy. Meas. 1970, 30, 607-610.

67. Kruskal, W.; Mosteller, F. Representative sampling I: Non-scientific literature. Int. Stat. Rev. 1979, 47, $13-24$.

68. Reis, J.; Forte, R. The impact of industry characteristics on firms' export intensity. Int. Area Stu. Rev. 2016, 19, $266-281$.

69. Almeida, A.; Oliveira, S. Estimated Health Sector Turnover in Portugal; Porto Business School: Porto, Portugal, 2014. 